\title{
Complexes of metal salts of groups I-VIII with trialkyl (aryl) phosphates
}

\author{
(C) Elena G. Zinovieva, ${ }^{*}$ and Vladimir A. Efimov \\ General, Inorgsnic and Analitical Chemistry Department. Chuvash State University. \\ Moskovsky Ave., 15. Cheboksary, 428015. Chuvash Republic. Russia. \\ Phone: +7 (8352) 45-24-68.E-mail: zinelgen@mail.ru
}

\begin{abstract}
*Supervising author; ${ }^{+}$Corresponding author Keywords: complex compounds, complexation, catalysis, oligomers, polymerization, polymers, modification, strength, fire resistance.
\end{abstract}

\begin{abstract}
The reactions of various inorganic salts of metals of groups I-VIII in the Periodic Table with trialkyl(aryl)phosphate compounds obtained new multifunctional complexes. Modern methods of physicochemical analysis studied the laws of complexation reactions. The influence of the nature and molar ratio of the starting trialkyl(aryl)phosphates, metal salts and their crystalline hydrates on the nature of the reactions between them has been revealed. It has been shown that organic phosphates with aromatic radicals are less reactive compared to trialkylphosphates. The presence of crystallization water in metal salts leads to a decrease in the rate of their reactions with trialkyl(aryl)phosphates. The most chemically active with respect to the trialkyl(aryl)phosphate compounds were tin and titanium tetrachlorides. Synthesized metalcomplex compounds were investigated as modifiers of polymer compositions. For polymer compositions, their viability was studied, which was determined by the gelation time and the compatibility of the composition with the metal complex; hardened polymer samples were tested according to standart methods for breaking stress at break, impact strength, elongation, resistance to aggressive chemical substance and fire resistance using the fire tube method. We have developed a method of obtaining epoxy polymers by carrying out two processes partial polymerization of the epoxy oligomer with solutions of trialkylphosphate complexes with Lewis acids in the corresponding trialkylphosphates at room temperature and the subsequent confirmation of the resulting prepolymer with triethylentetramine at $80^{\circ} \mathrm{C}$. It was revealed that trialkyl(aryl)phosphate complexes of metals are promising catalysts, modifiers and flame retardants for large-capacity polymers.
\end{abstract}

\section{References}

[1] E.G. Zinov'eva, V.A. Efimov, N.I. Koltsov, R.Z. Musin, M.N. Dimukhametov, A.T. Gubaidullin, D.B. Krivolapov. Synthesis and structure of tris (haloalkyl) phosphates complexes with metal chlorides. Journal of General Chemistry. 2008. Vol.78. No.8. P.1274-1279. (russian)

[2] E.G. Zinov'eva, D.A. Bezgin, V.A. Efimov, D.B. Krivolapov, R.Z. Musin, M.N. Dimukhametov, A.T. Gubaydullin. Formation of tetrakis[tri(2-chloroethyl)phosphate]diaquacobalt(II) tetrachlorobaltate (II). Russian Journal of General Chemistry. 2016. Vol.86. No.7. P.1772-1773. DOI: $10.1134 / \mathrm{S} 1070363216070409$.

[3] E.G. Zinov'eva, V.A. Efimov, N.I. Koltsov. Lewis acid complexes with tris(halo)alkylphosphates - new hardeners of epoxy resins. Plastics mass. 2008. No.2. P.32-33. (russian)

[4] E.G. Zinov'eva et al. The study of the kinetics of epoxy resin curing ED-20 trialkyl(aryl)phosphate complexes of Lewis acids and triethylenetetramine. Plastics mass. 2011. No.6. P.22-24. (russian)

[5] E.G. Zinov'eva, V.A. Efimov, N.I. Koltsov. Investigation of the properties of polymers of ED-20 epoxydian resin solidified with trialkyl(aryl)phosphate complexes of Lewis acids and triethylenetetramine. Plastics mass. 2011. No.7. P.3-5. (russian) 